\title{
Contents
}

\section{Year in review}

129 Year in review: health protection in NSW, 2011

Highlights health protection activities undertaken in NSW led by the Centre for Health Protection in 2011 and includes the annual review of notifications of communicable diseases in NSW. Centre for Health Protection

142 Sample size calculations for the design of health studies: a review of key concepts for non-statisticians Provides a guide to the statistical issues related to the calculation of sample sizes. A study from the Aboriginal Communities Water and Sewerage Program is used as an illustration.

Alistair Merrifield and Wayne Smith

148 Typhoid and paratyphoid fever in Western Sydney Local Health District, NSW, January-June 2011

A higher than usual number of typhoid and paratyphoid cases in Western Sydney Local Health District was investigated. Migrants returning home may underestimate the risk of infection and pre-travel typhoid vaccination would prevent some of these cases. Sarah J. Blackstock, Vicky K. Sheppeard, Jen M. Paterson and Anna P. Ralph
153 Trends and risk factors for hepatitis A in NSW 2000-2009: the trouble with travel

International travel to moderate-high endemicity countries continues to be the most common risk factor for hepatitis A in NSW. Pre-travel vaccination would prevent some of these cases.

Evan Freeman, Siranda Torvaldsen, Sean Tobin, Glenda Lawrence and C. Raina Maclntyre

HealthStats in the Bulletin

158 Overweight and obesity are common in rich and poor

\section{Bug Breakfast in the Bulletin}

159 Rapid health assessments

Nicola S. Scott, Michelle A. Cretikos and Matthew Cleary

160 One Health and Hendra virus: a collaborative approach in action

Belinda Crawford, lan Roth and Tiggy Grillo

Communicable Diseases Report, NSW

161 May and June 2012

\section{NSW PUBLIC HEALTH BULLETIN}

The NSW Public Health Bulletin is a peer-reviewed journal produced by the NSW Ministry of Health and indexed in Medline. It has a NSW focus, however, it aims to support the practice of public health more broadly.

\section{Editor}

Dr Lynne Madden

BSc(Med)Hons1, MBBS, MPH, MSc, FFPH, FAFPHM

\section{Editorial Manager}

Kristy Mannix

\section{Editorial correspondence}

Please address all correspondence and submissions to:

The Editor, NSW Public Health Bulletin Locked Mail Bag 961

North Sydney NSW 2059 Australia

Email: phbulletin@doh.health.nsw.gov.au

Telephone: +61 294245876

Fax: +61293919232

\section{Submission of articles}

The Bulletin accepts proffered and commissioned articles along with short reports, on all aspects of public health. Articles should be 1500-2000 words, not including tables and figures, and should include an abstract of up to 150 words. Articles should follow the journal style and layout as closely as possible, as described in the Instructions to Authors. Articles should be emailed in a Word forWindows format to: phbulletin@doh. health.nsw.gov.au, and should be accompanied by a covering letter signed by all authors and a License to Publish. The Instructions to Authors, License to Publish and other useful information can be downloaded from the Bulletin website.

\section{Distribution}

The Bulletin is freely available from the Bulletin website. Copies of the current issue and back issues can be downloaded in both PDF and HTML formats. If you would like to be notified when new issues of the Bulletin are available online, subscribe to the early alert email system at the Bulletin website. The early alert email contains the contents of each new issue along with electronic links to the articles. To receive a printed copy of the Bulletin, subscribe online at the Bulletin website, or contact your local public health unit or the editorial office.

eISSN 1834-8610

The Bulletin uses digital publishing at all stages of production as a priority over print. The Bulletin is printed on archival quality, chlorinefree paper using low volatility vegetable-based inks and uses computer-to-plate technology. The acid-free paper meets the standards of the American National Standards Institute for Information Sciences-Permanence of Paper for Printed Library Materials, ANSI Z39.48-1992.

Website: www.publish.csiro.au/journals/phb Copyright (c) 2012 NSW Ministry of Health 